\title{
A CRIAÇÃO E A UTILIZAÇÃO DOS BANCOS DE PERFIS GENÉTICOS PARA FINS DE PERSECUÇÃO CRIMINAL NO BRASIL: UMA ANÁLISE ATRAVÉS DA BIOÉTICA E DO ADVENTO DA LEI 12.654/2012
}

\author{
THE CREATION AND THE USE OF PROFILES OF BANKS FOR GENETIC \\ PROSECUTION PURPOSES CRIMINAL IN BRAZIL : AN ANALYSIS THROUGH \\ BIOETHICS AND BY THE ADVENT OF LAW 12,654 / 2012
}

\author{
${ }^{1}$ Carlos Eduardo Martins Lima
}

\section{RESUMO}

Esse artigo tem por objetivo expor em linhas gerais, a análise da utilização dos bancos de perfis genéticos para fins de persecução criminal no Brasil através do advento da lei 12.654 /2012 e por meio dos referenciais da bioética, dos documentos internacionais, dos princípios e garantias constitucionais e dos direitos humanos, buscando enfatizar a importância do uso dessa ferramenta criminalística e tecnologia no combate à criminalidade no Brasil. Além disso, por meio de uma reflexão crítica, busca-se analisar o diploma legal com enfoque no direito penal brasileiro e na genética forense, por intermédio do estudo da identificação humana. Ao final, busca-se uma conclusão sobre a efetividade do uso dessa tecnologia no âmbito criminal.

Palavras-chave: Palavras-chaves: bancos de perfis genéticos, Bioética, Documentos internacionais, Direitos humanos, Identificação humana

\begin{abstract}
This article aims to explain in general terms, the analysis of the use of banks of genetic profiles for criminal prosecution purposes in Brazil through the advent of Law 12,654 / 2012 and through the principles of bioethics, international documents, principles and guarantees constitutional and human rights, seeking to emphasize the importance of using this forensic tool and technology to fight crime in Brazil. Moreover, through critical reflection, we seek to analyze the legal instrument focusing on the Brazilian criminal law and forensic genetics , through the study of human identification. At the end, we seek a conclusion on the effectiveness of this technology in the criminal context
\end{abstract}

Keywords: banks genetic profiles, Bioethics, International documents, Human rights, Human identification

\footnotetext{
${ }^{1}$ Mestre em Direito pela Universidade do Vale do Rio dos Sinos - UNISINOS, São Leopoldo - RS (Brasil). E-mail: ceduardomlima@gmail.com
} 


\section{INTRODUÇÃO}

Os anseios em termos de segurança pública e as preocupações em termos de ameaças à privacidade tornam-se realidades palpáveis. O desafio é encontrar o adequado equilíbrio, de acordo com a normativa constitucional. Nesse pacote de riscos e benefícios estão incluídos temas de diversas ordens. O que eles têm em comum é provocar o questionamento constante das verdades sobre as quais os seres humanos fundam suas ciências, suas economias, suas políticas e seus sistemas de normas. Nunca, talvez, problemas tão microscópicos, como aqueles vinculados à genética molecular, exigiram soluções tão macroscópicas do ponto de vista político-econômico e, por que não, jurídico (SCHIOCCHET, 2012).

O uso frequente de análise genética no âmbito forense, associados ao progresso na informática, permitiu a criação de bancos de perfis genéticos com propósito de investigação criminal. Esses bancos são bases de dados onde as informações genéticas são armazenadas com intuito de identificação civil ou investigação criminal, ou seja, são bases estruturadas de resultados de análises de perfis genéticos indivíduo-específicos. A partir da comparação de perfis genéticos obtidos em cenas de crimes ou das pessoas envolvidas nos mesmos, com os padrões genéticos armazenados em bancos de DNA, há a possibilidade de indicar a autoria de atos delituosos ou de inocentar suspeitos (CASABONA, 2002).

O presente estudo tem como foco principal discutir aspectos bioéticos envolvidos na implantação do Banco Nacional de Perfis Genéticos Criminal no Brasil, um projeto da Polícia Federal juntamente com o Ministério da Justiça. Os primeiros passos para a regulamentação desse banco foram dados com a publicação da Lei de $n^{\circ}$ 12.654/2012 que dispõe sobre a coleta e armazenamento de material genético para fins de identificação criminal a critério do juiz.

A criação de um banco como esse fez surgir questionamentos éticos e legais no meio jurídico, acadêmico, bioético, em especial, nas comissões de ética (BONACCORSO, 2010). Como exemplo, podem ser citadas as questões ligadas aos aspectos funcionais, estruturais, de gestão, de segurança dos dados e ao tempo de permanência dos dados no banco; os aspectos relacionados à privacidade dos dados genéticos, ao fornecimento de consentimento livre e esclarecido de doação de material biológico, à transgressão de direitos e liberdades fundamentais.

Na sociedade de risco, que tende a ser também uma sociedade autocrítica, é importante que o debate de temas de grande relevância social seja aberto à participação de diversos agentes, 
pois este não deve continuar fechado somente à participação de especialistas no assunto, o que de certa forma possibilita a socialização das tomadas de decisões (BECK, 1997, p.11)

É importante lembrar que os conflitos éticos caminham junto com a história do homem uma vez que advêm de suas ações e, que podem adquirir maior ou menor relevância a depender do contexto temporal em que surgem. Tais conflitos são colocados em destaque quando analisados a partir de visões diferentes e à medida que ocorre a tomada de consciência por parte da sociedade, sobre a necessidade de impor limites à utilização de novas tecnologias na tentativa de garantir a integridade da pessoa humana e do meio em que vivem. De alguma forma, isso pode proporcionar subsídios à normatização e à implementação de novos projetos de cunho científico ou social (GARRAFA, 2003, p. 56).

A reflexão sobre a eticidade do uso de um banco de dados dessa natureza se justifica pelos riscos de desrespeito de direitos e liberdades fundamentais, como o direito à vida privada, e de desrespeito à autonomia dos doadores de material genético para a inclusão no banco e, ainda, pela necessidade de se ampliar o debate, exigindo um olhar mais atento da sociedade para a elaboração de políticas públicas sobre o tema.

Nesse sentido, a bioética é chamada a contribuir em situações que envolvam interesses coletivos e individuais, e a possibilidade de desrespeito à dignidade humana de indivíduos em situação de vulnerabilidade. Segundo Garrafa (2003, p.56), a bioética é caracterizada por derivar da análise processual dos conflitos baseada em uma ética minimalista, almejando a mediação e a solução pacífica dos conflitos envolvidos.

Visto que, para ninguém é conveniente tentar impedir o avanço da ciência e da tecnologia, é justo que o mesmo seja pautado pela responsabilidade pública e individual e pelo respeito à cidadania, com intuito de se maximizar os benefícios e minimizar os malefícios (KOTTOW, 2003, p.56).

\section{A BIOÉTICA}

A bioética, como uma ética aplicada à vida, busca se relacionar com as questões de direitos humanos e de cuidados com a vida em sua plenitude, dentre outros. A mesma agrega valores morais, sejam estes denominados direitos, princípios, virtudes ou cuidados (GARRAFA, 2006). A evolução das ciências biológicas e das tecnologias aplicadas a análise do DNA, especialmente no século XXI, fez com que surgissem novas possibilidades de 
intervenções nessa área. Juntamente com essas novas tecnologias, emergiram novos conflitos éticos jamais antes concebidos e, para os quais não há respostas prontas (CRUZ; CORNELLI, 2010, p. 115-138).

Para se buscar uma mediação a estes conflitos é necessário analisá-los a partir de um prisma transdisciplinar, sendo a bioética o campo do conhecimento que proporciona esse debate, estabelecendo um diálogo entre os diferentes ramos do saber na busca de soluções eticamente adequadas a tais controvérsias. Dessa forma, a bioética recusa qualquer projeto globalizante, qualquer sistema fechado de pensamento, reconhecendo a urgência de uma troca dinâmica entre as ciências biológicas e as ciências humanas.

O nascimento da bioética está associado a acontecimentos históricos e personagens. Segundo sugere alguns autores, o médico Fritz Jahr teria sido o primeiro estudioso a utilizar a palavra bioética, ao propor, em 1927, em um artigo publicado no periódico alemão Kosmos (JAHR, 1927), uma ética de respeito a todos os seres vivos. Mais tarde, em 1971, Van Rensselaer Potter, preocupado com questões que envolviam a ecologia, a degradação do meio ambiente e a sobrevivência da vida no nosso planeta, propôs um conjunto de valores morais e interfaces diferentes daquela provocada inicialmente por Fritz e denominou também de bioética (GOLDIM, 2006, p. 86-92). No mesmo ano, André Hellegers, ginecologista e obstetra, fundou o Kennedy Institute, na Universidade de Georgetown. Este médico, preocupado com a ética médica que não conseguia ajudar os profissionais nas difíceis decisões sobre o uso ou não de biotecnologias, criou o renomado instituto com o objetivo de abranger parâmetros morais além do código de ética hipocrático, para uma ética mais ampla, que ele também chamou de bioética (JUNGES, 2011, p. 171-178).

A origem da bioética pode também ser atribuída a outros fatos. Dentre estes está a publicação, em 1966, do artigo de Henry Beecher no The New England Journal of Medicine, sobre os abusos de médicos em relação aos pacientes em experimentos clínicos controversos e abusivos. O exemplo mais contundente destas experimentações absurdas foi o "caso Tuskeege", em que homens negros sifilíticos foram usados, por cerca de 40 anos, em experimentos clínicos sobre a sífilis, cujo objetivo era observar a evolução natural da doença sem tratamento. Essa experimentação abusiva teve uma conivência criminosa por parte da comunidade científica geral dos Estados Unidos, haja vista que artigos foram publicados sobre os resultados sem que ninguém se opusesse a essa transformação de seres humanos em “cobaias”. (BEECHER' 1966, p 1354-1360). 
A reação da população, impulsionada por ideais de direitos humanos e ativistas do movimento negro e feminista (DINIZ; GUILHEM, 2000), forçou o governo americano a criar, em 1974, a “Comissão Nacional para Proteção de Sujeitos Humanos nas Pesquisas Biomédicas e Comportamentais". Em 1978, a comissão apresentou um relatório intitulado: "Relatório Belmont: Princípios Éticos e Diretrizes para a Proteção de Sujeitos Humanos nas Pesquisas" a respeito dos trabalhos realizados (NATIONAL COMMISSION FOR THE PROTECTION OF HUMAN SUBJECTS OF BIOMEDICAL AND BEHAVIORAL RESEARCH). Este relatório, que apresentava diretrizes morais que deviam pautar pesquisas com humanos, é considerado um marco histórico dentro do crescimento exponencial dos ideais bioéticos propostos por Potter. Essas diretrizes ficaram conhecidas em toda a comunidade científica como os três primeiros princípios da bioética: respeito às pessoas, depois denominado de autonomia, beneficência e justiça (JUNGES, 2011, p. 171-178).

Contudo, a bioética obteve expansão mundial pela publicação do livro Principles of Biomedical Ethicsem 1979 (BEAUCHAMP; CHILDRESS, 2001). Nessa obra, os autores Beauchamp e Childress propõe a ampliação dos três princípios universais expressos no Relatório Belmon - a beneficência, a justiça e o respeito à autonomia - para quatro, com a inclusão da não maleficência. Os princípios universais são geralmente aplicados na busca de ponderação dos prós e contras em determinadas situações, isto é, são evocados na tentativa de resolução de conflitos. Apesar de muito criticado Garrafa (2005), é ainda pertinente e satisfatório quando aplicado à pesquisa envolvendo seres humanos e em casos de limite de atuação da ciência (SCHRAMM, 2008, p. 361-370).

Atualmente na bioética, as pesquisas biotecnológicas tendem a ser orientadas, também, por outros princípios éticos ou até com concepções éticas estranhas ao principialismo. No entanto, ao associar esses outros princípios éticos num modelo de princípios prima facie, sem que nenhum princípio tenha prioridade sobre os demais, acontece uma abordagem do fenômeno pelos princípios de forma integrada. Isso geralmente origina modelos normativos e conceituais, porém, ainda se destaca o modelo principialista. Desta forma, a fundamentação da bioética em princípios está no fundamento de muitas resoluções e diretrizes acerca das condições éticas necessárias para se desenvolver pesquisas biotecnológicas, como é o caso da manipulação genética para a criação do banco de dados genéticos para fins criminais (SCHRAMM, 2008, p. 361-370).

Dentro do contexto dos quatro princípios tradicionais, verifica-se que há um desdobramento do princípio do respeito à autonomia e da justiça, em correntes paralelas ao 
contexto desses dois princípios. O princípio do respeito à autonomia se desdobra na confidencialidade e privacidade do indivíduo e divide a responsabilidade do respeito à autonomia com o princípio de respeito à informação individual. Já o princípio da justiça se desdobra em equidade, pois se entende que uma situação justa deve possuir uma delineação equânime entre os dados a serem analisados.

A bioética, atualmente, vem estendendo sua discussão sobre políticas públicas, econômicas e sociais, com a finalidade de intervir nas questões de abuso e injustiças. Portanto, vislumbra-se a necessidade de se refletir e discutir, sob seu amparo, um equilíbrio entre a criação de políticas de segurança públicas (como a implantação do banco de dados) cada vez melhores para a sociedade e a intervenção de mecanismos legitimadores no sentido de preservar a dignidade da pessoa humana, de acordo com os referenciais da bioética. Essa discussão traz à tona uma série de questionamentos acerca da eticidade da implantação dessa nova ferramenta da criminalística.

\subsection{Identificação Humana}

Busca-se abordar os fundamentos da técnica de identificação conhecida por DNA Profillig e, em particular, dos princípios da genética que estão na sua origem e que são indispensáveis à compreensão das técnicas e dos seus contextos em usos forenses.

Os primeiros trabalhos que vieram a ter uma influência decisiva no entendimento da genética e na descoberta de unidades de transmissão de caracteres (que mais tarde viria a ser conhecido como genes), devem-se a Gregor Mendel, em 1865. Interessado em estudar a respiração das plantas e como se diferenciavam as suas sucessivas gerações. Mendel cruzou diferentes linhagens de plantas diferindo apenas uma característica, observando aquilo que se viria a chamar de estrutura fenotípica, ou seja, aspectos exteriormente identificáveis das plantas, como a textura, altura e cor (COSTA, 2003, p.18).

Ainda que apenas interessados na estrutura fenotípica, os estudos encetados por Mendel permitiram verificar, a partir da distribuição dos caracteres relevantes em sucessivas gerações, que certas características nas plantas se mantinham imutáveis de geração para geração (COSTA, 2003, p.25). Esses estudos viriam a tornar-se de grande utilidade na descoberta, um pouco mais tarde, da existência do genótipo. A partir dos trabalhos de Mendel, mas centrandose já não no fenótipo, mas antes no genótipo e no funcionamento da célula, os estudiosos da hereditariedade virão a propor o termo "gene" por volta de 1909. 
Segundo Costa, o gene viria, assim, a torna-se 'the fundamental physical and functional unit of heredity', isto é, um trecho da molécula de ADN que se encontra estruturado em cromossomos, ou veículos de hereditariedade, e que é transmissível de pais para filhos (COSTA, 2003, p.26).

De acordo com Costa, o ácido desoxirribonucleico é o material químico que compõe cada molécula encontrada nos cromossomos, que permite especificar a composição das proteínas e que transporta a informação genética de cada organismo. No entanto, seria preciso quase mais um século, depois dos trabalhos de Mischer, até que o ADN fosse descrito como material genético constituído por uma dupla hélice, isto é, duas longas moléculas de nucleótidos em forma espiral que se formam paralelamente. Esta descoberta deve-se a Watson e Crick, em 1953 (COSTA, 2003, p.26).

Segundo Costa (2003), a técnica que permite identificar um indivíduo com base numa sequência específica de nucleótidos foi frequentemente descrita como impressão digital de ADN ou DNA fingerprinting. Depois do seu aparecimento, em contextos forenses, em 1985, na Inglaterra, seria adotada nos Estados Unidos, um ano depois e em 1988 era já uma das técnicas de identificação usadas pelo FBI (Federal Bureau of Investigation). A partir de então, a técnica espalhou-se pelo mundo, sendo atualmente usada em muitos países, em processos civis e penais.

O ADN é, hoje, considerado um aspecto fulcral da identidade humana, e mesmo, por alguns, como elemento definidor, por excelência, das características únicas de cada ser humano. As células de que é constituído o organismo de cada indivíduo contém, cada uma, um núcleo, que é a parte o organismo de cada indivíduo contém, cada uma, um núcleo, que é a parte da célula onde se encontram 46 cromossomos divididos em 23 pares: metade provém do pai e a outra metade da mãe. Assim todos os núcleos das células de um dado indivíduo contêm o mesmo número e o mesmo tipo de cromossomos, observáveis microscopicamente, em que se encontram os genes (COSTA, 2003, p.28).

De acordo com Costa, cada um dos cromossomos tem como sua espinha dorsal, uma longa molécula de ADN com a forma de uma dupla hélice. As proteínas, cadeias de aminoácidos necessárias à estrutura, função e regulação da atividade celular, são codificadas por sequências específicas de nucleótidos a partir do ADN. A sequência de nucleótidos que determina a síntese dos amino-ácidos em proteínas é geralmente designada de código genético (COSTA, 2003, p.29). 
Introduzidas as noções básicas da genética molecular, passa-se a abordar sobre como se processa tecnicamente a identificação do perfil genético.

Desde os tempos mais remotos já havia a necessidade de identificação do indivíduo. Enquanto no passado a identificação humana tinha como objetivo apontar criminosos, atualmente ela visa à fixação da personalidade jurídica do indivíduo para todos os seus atos. Os métodos de identificação foram aperfeiçoados ao longo dos anos e hoje é possível estabelecer a identidade de um ser humano com alta precisão (BARALDI, 2008).

O termo identidade, do ponto de vista da criminalística, pode ser considerado como um conjunto de sinais, características pelas quais se podem individualizar uma pessoa, tornandoa distinta das demais. Já identificação, é um termo que corresponde aos vários processos, métodos e sistemas usados para reconhecer um indivíduo, ou ainda atos a partir dos quais a identidade de alguém pode ser determinada (JOBIM,2006).

A identificação humana teve seu início, propriamente dito, com o método antropométrico de Bertillon no ano de 1882, que considerava características morfológicas e cromáticas, a exemplo, do formato do queixo, lóbulo da orelha, cor da pele ou cabelos e posição de sobrancelhas. As características biológicas que podiam identificar pessoas ou grupos foram usadas para determinar o perfil criminológico até o início do século XX e, juntamente com as características psicológicas implantaram o caráter bio-psicológico da criminologia (GARRIDO, 2009, p. 38-40).

$\mathrm{Na}$ identificação humana são considerados métodos de identificação conclusivos as impressões papilares (digitais, plantares e palmares), o desenho do palato, dos seios faciais e da arcada dentária; as impressões labiais, da íris, e do DNA. Já os métodos não conclusivos são as marcas e tatuagens, o tamanho do pé, a tipagem sanguínea (ABO, Rh), a identificação visual e impressão auricular (ESPINDULA, 2009).

As impressões digitais foram até pouco tempo tidas como a maior estrela da identificação criminal, devido sua possibilidade de diferenciar um indivíduo dentre todos os demais e pelo fato da simples presença de uma impressão digital em uma cena de crime ser um indício criminal muito forte (ACOSTA, 2002, p.25). No entanto, o processo de identificação humana por meio das técnicas de análise do material genético, a partir da metade do século passado, tornou-se o grande destaque da individualização humana na contemporaneidade.

A utilização das técnicas genéticas na identificação humana teve início com a análise dos sistemas sanguíneos $\mathrm{ABO}$ e Rh, evoluindo para o uso de vários grupos sorológicos variantes 
da hemoglobina, sistema HLA, até chegar ao material genético, a partir do ano de 1980, com a descrição do primeiro marcador polimórfico de tamanho de fragmentos de restrição (RFLP), pelo pesquisador Ray White. Posteriormente, com a criação da técnica da PCR (reação em cadeia de polimerase), em 1985, passou-se a utilizar os exames de DNA, de forma mais ampla na identificação humana (GARRIDO, 2009, p.38-40).

É importante frisar que a análise da molécula de DNA não aponta para uma única pessoa, mas indica, a princípio, a probabilidade estatística de inclusão da mesma na cena do crime. Isto possivelmente coloca o exame de DNA, como uma poderosa ferramenta para associar diretamente vítimas e/ou suspeitos a um ato delituoso. Especialmente, a partir de sua associação com o conjunto de provas levantadas durante o processo investigativo.

Por ser um exame comparativo, a análise do DNA é geralmente utilizada em casos criminais em que existe a figura do suspeito. Em crimes sexuais, por exemplo, o material encontrado na cena do crime e/ou no interior da vítima, somente pode ser comparado com material coletado de suspeitos indicados pela investigação criminal.

No Brasil, a identificação civil é atestada por carteira de identidade ou por qualquer documento público que permita a identificação do indivíduo. Contudo, a identificação criminal era realizada somente por meios dos processos datiloscópicos e fotográficos em casos de flagrante delito, de indiciamento em inquérito policial, de prática de infrações penais de menor gravidade e em casos de mandado de prisão judicial expedido contra si (ESPINDULA, 2009). Pois até pouco tempo não existia uma regulamentação acerca da identificação por meio da técnica de análise do DNA.

Entretanto, com a publicação da Lei 12.654, de Julho de 2012 (este instrumento legal será analisado em campo próprio), que prevê a coleta de perfil genético como forma de identificação criminal, esta realidade foi alterada. O que abriu precedente para a criação de um banco nacional de perfis genéticos criminais - ferramenta bastante utilizada por vários países do mundo para auxiliar na investigação criminal e, por conseguinte, na identificação de criminosos.

Nesse momento, é adequado apresentar algumas especificações dos bancos de dados de perfis genéticos com finalidade criminal. 


\section{BANCO DE PERFIS GENÉTICOS PARA FINS DE PERSECUÇÃO CRIMINAL}

O acúmulo de dados é sem dúvida um ato necessário na modernidade, não se podendo impedir nem mesmo diminuir a sua autogeração, pois eles são úteis para a sociedade em geral e para os cidadãos em particular (ACOSTA, 2002, p.25).

De uma forma sucinta, pode-se considerar que os bancos de dados de perfis genéticos para fins forenses são bases que armazenam dados procedentes de indivíduos já condenados por tipos específicos de crimes ou, a depender do país, de suspeitos ou indiciados, bem como, perfis obtidos de vestígios biológicos encontrados em locais de crimes; e em alguns casos, perfis de vítimas.

Os bancos de dados de DNA podem ser classificados pelo seu conteúdo ou pela sua finalidade. De acordo com o conteúdo os bancos podem ter dados alfanuméricos, DNA extraído ou material biológico. Entretanto, os bancos que contêm somente dados alfanuméricos são considerados bancos de dados propriamente ditos. Os depósitos de amostras biológicas e DNA extraídos são denominados de biobancos. Os bancos com propósito de identificação genética são compostos por números associados ao código de identificação de um indivíduo (BONACCORSO, 2010). Eles podem ser implantados com objetivo de identificar pessoas desaparecidas, pessoas vítimas de acidentes ou em atos terroristas em que o corpo encontrase irreconhecível, e ainda, com objetivo de identificar os autores de delitos criminais (MORA, 2002, p.45-73).

Esses bancos podem diferir quanto às formas de constituição, especialmente, no que se refere ao tempo de permanência dos perfis genéticos na base de dados, em alguns deles os dados permanecem por tempo indefinido na base (como ocorre na Inglaterra, Noruega e Áustria). Na sua grande maioria os bancos são constituídos por perfis genéticos de condenados, por amostras de suspeitos e/ou por amostras anônimas coletadas em locais de crimes. A Alemanha é o único país que não dissocia os dados pessoais dos dados genéticos de cada indivíduo, mantendo-os em uma mesma base (GARCIA, 2002, p. 27-43).

Uma característica intrigante desses bancos é que alguns dados e amostras são, muitas vezes, obtidos sem consentimento das pessoas envolvidas, a exemplo do que acontece no Reino Unido, na Holanda e na Alemanha. Sua finalidade principal é colaborar com as investigações de casos judiciais criminais, utilizando a prova genética para identificar a autoria do crime, por meio da comparação automatizada de perfis de DNA obtidos de vestígios de cena de crime com 
os perfis obtidos das amostras referências - amostras biológicas de vítima e dos suspeitos ou condenados (ACOSTA, 2002, p.25).

Como já abordado anteriormente, outra forma de fazer uso de um banco é realizando pesquisa familiar. Esta busca dentro do banco é usada quando não há coincidência total (coincidência de 15 ou mais alelos) entre o perfil de DNA obtidos do local de crime e os perfis armazenados no banco de dados (BONACCORSO, 2010). É realizada uma varredura à procura de coincidências parciais, a fim de identificar possíveis parentes do autor do dado crime.

Um aspecto interessante é que o banco de dados de perfis de criminosos está dissociado do banco de dados que identificam estes criminosos, melhor dizendo, os perfis genéticos são armazenados em espaço físico distinto dos dados de identificação (GARCIA, 2002, p. 27-43). Evitando, com isso, a associação dos perfis genéticos aos dados pessoais dos indivíduos que forneceram esses perfis. O que possibilita a garantia da privacidade e da intimidade dos indivíduos envolvidos.

Similarmente ao que aconteceu em outros países, a criação de um banco de perfis genéticos com finalidade forense no Brasil é apresentada como estratégia política e de governo para prevenção e redução da criminalidade. Na opinião de Machado e Silva (2011, p. 153-166), esta é uma estratégia que se apoia na retórica da grande eficácia e confiabilidade da genética forense - das técnicas de identificação humana por meio da análise do DNA -, o que tem diminuído significativamente o espaço para críticas a essa premissa. Sobretudo pelo fato da tecnologia de DNA forense ser encarada como a prova pericial mais confiável e pelo seu elevado padrão de eficiência.

O uso de diversos microssatélites do DNA, para determinar a autoria de um delito e, a comparação de uma amostra problema com perfis genéticos armazenados em bancos de dados forenses, é uma realidade que se faz presente em vários países no mundo, como: Estados Unidos, Reino Unido, Espanha, Inglaterra, Alemanha, Áustria, Canadá, Chile, Colômbia, Dinamarca (COLE, 2002).

As primeiras discussões sobre a criação de um banco de dados de perfil genético com essa finalidade surgiram nos Estados Unidos, em 1989. Um software piloto do atual sistema CODIS foi lançado em 1990. No ano seguinte, mais ou menos quinze Estados Americanos já haviam promulgado leis autorizando a implantação de um banco de dados de DNA criminal. Em 1994, foi estabelecido por meio legal o sistema em escala nacional - o National DNA Index System (NDIS) (LIMA, 2008, p. 8-11). 
Já na Europa, o tema começou a ser discutido em 1991, com a Reunião do Comitê ad hoc de Peritos nos avanços das Ciências Biomédicas (CDBI). O Conselho da Europa estabeleceu recomendações sobre o uso das análises de DNA no sistema criminal (ALMEIDA, 2008). No entanto, o banco inglês foi o primeiro banco nacional de perfis genéticos a ser criado, no ano de 1995, e atualmente, o banco de dados mais importante é o dos Estados Unidos, denominado CODIS, elaborado pela agência governamental norte-americana, FBI (Federal Bureau of Investigation).

O FBI desenvolveu alguns estudos a despeito da variabilidade dos STRs (do inglês, short tandem repeats ou repetições curtas em tandem, em português) e selecionou um conjunto de 13 STRs para compor o sistema CODIS. A probabilidade de ocorrência estimada para o perfil composto pelos genótipos mais frequentes de cada um dos 13 marcadores é cerca de 1 em 160 bilhões, a utilização desse conjunto de marcadores permite assegurar que cada indivíduo da população mundial apresente um perfil alélico exclusivo, com exceção, é claro, dos gêmeos idênticos (MARANO, 2010). O CODIS é um sistema de banco de dados, em que todos os estados norte-americanos estão interligados, onde perfis de DNA de criminosos e amostras encontradas em cenas de crimes são armazenados. Este sistema é constituído por dois arquivos contendo perfis genéticos, um com perfis genéticos obtidos de cenas de crimes - Forensic Index - e outro contendo perfis de criminosos condenados por crimes sexuais e outros crimes violentos - Offender Index (GATTÁS, 2007).

Cópias do software do CODIS são fornecidas a vários países no mundo. Atualmente, mais de 25 países utilizam o CODIS em seus laboratórios forenses e respectivos bancos de dados. Esse software apresenta quatro principais funções: entrada e gestão de perfis de DNA; busca de perfis; gestão dos resultados da pesquisa, o que permite indicar se a ocorrência de uma determinada coincidência se deu entre um criminoso e um vestígio ou entre vestígios e, ainda, apontar em que jurisdição ocorreu o crime; e, por fim, a função de cálculos estatísticos, a partir dos quais se pode determinar a frequência de ocorrência de um determinado perfil na população (BONACCORSO, 2010).

É valido lembrar que a responsabilidade sobre a gestão de um banco de dados com fins criminais possui grande relevância, sobretudo pelo motivo dessas bases de dados serem fontes de informações especiais e, portanto, devem ter acesso restrito. Tal relevância pode ser evidenciada nas palavras de Romeo Casabona (2002): 
De todo modo, estas provas originam problemas novos e acentuam outros já estabelecidos anteriormente em relação com as provas biológicas, respeito às quais não se trata de primar ou obstaculizar sua utilização, senão de assegurar que se realizem com as suficientes garantias técnicas processuais e de respeito aos fundamentos que puderam ver-se afetados.

Nos países que possuem bancos de dados dessa natureza, as legislações recomendam que a gestão seja feita por órgão de natureza pública ou semipública, na tentativa de garantir um funcionamento adequado do banco. Em muitos desses países a gestão nacional fica a cargo da polícia federal, a exemplo dos Estados Unidos onde a gestão nacional é feita pelo FBI e a local pelos laboratórios estaduais. Ao passo que em outros, a gestão é realizada pelos Laboratórios das Polícias Científicas e pelo Instituto Nacional de Medicina Legal, o que acontece em Portugal.

Nesse momento, é interessante caracterizar os bancos de perfis genéticos em vários países do mundo, para só então entrar na seara do banco brasileiro.

Em Portugal, conforme a Lei ${ }^{\circ}$ 5/2008 de 12 de fevereiro, a criação de uma base de dados de perfis genéticos para fins de identificação civil e criminal foi aprovada, com as seguintes características: uma base com perfis de condenados, onde são incluídos indivíduos condenados por crime doloso com pena igual ou superior a três anos de prisão, mediante decisão judicial; outra base com perfis de voluntários que obrigatoriamente devem prestar seu consentimento livre, informado e escrito para a coleta de material biológico; uma base contendo perfis de amostras problemas coletadas em cenas de crimes; e, por último, uma base com informações de cadáveres não identificados e de pessoas desaparecidas para fim de identificação civil. Quanto ao tempo de permanência do perfil na base vai depender da duração da pena condenatória e a eliminação do perfil ocorre logo após o cumprimento da mesma.

$\mathrm{Na}$ Inglaterra tem-se um dos bancos de perfis genéticos criminais mais rígidos e abrangentes do mundo, com a inclusão de uma grande proporção da população (8). Em 1995, foi estabelecida a primeira base nacional de dados de DNA do mundo, a National DNA Database - NDNAD - o banco inglês de perfis genéticos. Nela está incluído o perfil genético de todas as pessoas que cometeram "qualquer infração penal”. A lei britânica estabelece que as amostras biológicas e os perfis sejam detidos por tempo ilimitado. De acordo com o último Annual Report publicado pelo banco inglês, em 2010, existem armazenados em sua base de dados o perfil genético de mais de 4.859 .934 pessoas (NDNAD, 2010). 
São também exemplos de banco de grande abrangência quanto à inclusão de perfis genéticos, os bancos da Áustria, Eslovênia e Suíça.

Diferentemente de Portugal, a Holanda, após a Reforma do Código de Processo Penal, de 1994, realiza todos os testes de DNA, sem o consentimento do suspeito e mediante autorização judicial, em crimes com pena de prisão de oito ou mais anos, nos casos de estupro e abuso sexual. Recentemente, passou a incluir delitos com pelo menos quatro anos de prisão (VÁZQUEZ, 2004).

Nos Estados Unidos da América, por sua vez, as leis federais garantem a recolha de material genético de americanos presos por crimes federais - mesmo antes de qualquer julgamento - e de imigrantes ilegais que estejam detidos pelas autoridades, por qualquer que seja o crime. O CODIS, até janeiro de 2013, possuía nas suas bases de dados mais de 10.142.600 perfis genéticos de condenados armazenados e 472.500 de perfis genéticos obtidos de vestígios retirados de cenas de crimes. Nesse mesmo período, mais de 200.300 consultas foram realizadas ao CODIS em assistência a mais de 192.400 investigações criminais (VÁZQUEZ, 2004).

O banco canadense se estabeleceu oficialmente no ano 2000. A legislação canadense obriga a doação compulsória de material genético, mediante determinação judicial, nos casos de crimes mais graves como homicídio, sequestro e estupro. O tempo de armazenamento do perfil genético se dar até o prazo de cumprimento da pena de prisão. No ano de 2012, o banco canadense contabilizou cerca de 237.000 perfis genéticos de condenados e 71.000 perfis obtidos de cenas de crimes, de acordo com dados retirados de seu annual report.

Quanto ao tempo de arquivamento das amostras biológicas e de seus respectivos perfis genéticos, as legislações internacionais em vigor são bastante variadas. Podendo ser encontrados bancos em que os perfis são arquivados por tempo indefinido, bancos onde eles permanecem arquivados enquanto a pessoa viver e enquanto dure a sentença condenatória; e, aqueles que ficam armazenados na base até o delito prescrever; e, ainda, aqueles que o tempo de arquivamento vai depender da idade do indivíduo (VÁZQUEZ, 2004).

É possível ainda fazer uma análise comparativa entre diferentes países no que tange ao tempo de armazenamento de perfis genéticos: na Alemanha, Áustria, Hungria, Suíça, Finlândia, os perfis de suspeitos permanecem armazenados enquanto durar a apuração do crime. Por outro lado, na Inglaterra, o perfil nunca é removido, mesmo se os suspeitos forem absolvidos. Por fim, na maioria dos países, os perfis de condenados ficam por um longo período de tempo na base de dados, entre 40 e 50 anos (VÁZQUEZ, 2004). 
Um ponto importante, que foi motivo de grande discussão em vários países, é a definição de quais os tipos de crimes que serão considerados para a inclusão de perfis genéticos nos bancos de dados. Pois os critérios de inclusão devem ser bem restritivos, a princípio. Sendo necessário haver uma ligação a priori entre o indivíduo, o banco e o crime a ser investigado. Nesse sentido, quatro variáveis devem ser consideradas para justificar o arquivamento do perfil na base: o tipo de delito, a gravidade e o índice de recorrência destes e a possibilidade de originarem vestígios biológicos ou não.

No Brasil, os primeiros passos na direção da implantação do banco nacional de perfis genético criminal foram dados em maio de 2010, quando o governo brasileiro assinou um acordo com o FBI, para a utilização do software CODIS. Assim, a princípio, o banco brasileiro teria os mesmos padrões do banco norte-americano, e esta foi a maior instalação do sistema CODIS já feita até o momento (AGUIAR, 2011). Instalou-se o CODIS 5.7.4, com finalidade criminal, e o CODIS 6.1 para identificação de pessoas desaparecidas e de vítimas de desastre em massa (SCHIOCCHET, 2012).

A partir disso, permitiu-se a criação de uma Rede Integrada de Banco de Perfis Genéticos (RIBPG) - projeto em parceria da SENASP (Secretária Nacional de Segurança Pública), da Polícia Federal e das Secretarias Estaduais de Segurança Pública -, o que possibilitou o compartilhamento e a comparação de perfis genéticos em todo o país. Este compartilhamento ocorre por meio de um banco central, onde todos os laboratórios forenses estaduais estão associados (BONACCORSO, 2010).

Já em 2011, os bancos de perfis genéticos estaduais iniciaram suas atividades, armazenando materiais genéticos coletados em locais de crimes, para posterior comparação com o perfil genético de indivíduos, suspeitos ou condenados pela prática de determinados crimes (SCHIOCCHET, 2012).

Em princípio, 15 estados da federação já possuem laboratórios especializados que participam da Rede Integrada de Bancos de Perfis Genéticos, são eles: Amazonas, Amapá, Bahia, Ceará, Espirito Santo, Mato Grosso do Sul, Minas Gerais, Pará, Paraíba, Pernambuco, Paraná, Rio de Janeiro, Rio Grande do Sul, Santa Catarina e São Paulo. Assim como o Distrito Federal, a Polícia Federal também possui um laboratório credenciado à rede (BONACCORSO, 2010).

Investimentos, criação de novos laboratórios, aquisição de equipamentos e reagentes são de responsabilidade da SENASP; e recurso pessoal, capacitação e atualização dos 
profissionais e controle de qualidade dos laboratórios estão sob a responsabilidade da Polícia Federal e das Secretarias de Segurança Públicas estaduais (SCHIOCCHET, 2012).

Até o início do ano de 2012, a análise de DNA era usada apenas na investigação criminal especifica que deu origem à coleta de material biológico. Ou melhor, em casos de investigação denominados de casos fechados, onde há vestígios coletados na cena do crime e coletados da vítima ou do suspeito.

No entanto, em maio desse mesmo ano, foi publicada a Lei $\mathrm{n}^{\circ} 12.654$ (comentada em seção anterior), regulamentada pelo Decreto de $n^{\circ} 7.950$ de 12 de março de 2013, que estabeleceu a identificação genética como forma de identificação criminal, e possibilitou a implantação e utilização do banco nacional de perfis genéticos criminal.

\section{A LEgislaçÃO QUE CRIA E REgULAMENTA O BANCO DE PERFIS GENÉTICOS CRIMINAL BRASILEIRO: A LEI 12.654/2012}

A Lei $n^{\circ} 12.654 / 12$ tem sua origem no projeto de Lei $n^{\circ} .2 .458 / 2011$, de autoria do senador Ciro Nogueira (PP-PI).52 Após tramitação no Congresso Nacional, foi o projeto aprovado, sancionado pela presidente e publicado no Diário Oficial da União no dia 29 de maio de 2012 como Lei $\mathrm{n}^{\mathrm{o}}$ 12.654/12, entrando em vigor em todo o território nacional a partir de novembro de 2012.

Com apenas quatro artigos, a Lei de $\mathrm{n}^{\mathrm{o}}$ 12.654/2012 dispõe sobre a coleta e armazenamento de material genético para fins de identificação criminal a critério do juiz. Para tanto, altera as Leis $n^{\circ} 12.037 / 2009$ - que trata da identificação civil e criminal - e de $n^{\circ}$ 7.210/1984, a Lei de Execução Penal (12).

A característica principal dessa Lei encontra-se estabelecida em seu art. $2^{\circ}$, elaborado a fim de modificar o artigo $9^{\circ}$ da Lei de Execução Penal de 1984. Como se pode verificar abaixo:

Art. $9^{\circ}$-A. Os condenados por crime praticado, dolosamente, com violência de natureza grave contra pessoa, ou por qualquer dos crimes previstos no art. $1^{\circ}$ da Lei $\mathrm{n}^{\text {o }}$ 8.072, de 25 de julho de 1990, serão submetidos, obrigatoriamente, à identificação do perfil genético, mediante extração de DNA - ácido desoxirribonucleico, por técnica adequada e indolor.

$\S 1^{\circ}$ A identificação do perfil genético será armazenada em banco de dados sigiloso, conforme regulamento a ser expedido pelo Poder Executivo. 
Nestes termos, fica instituída a coleta compulsória de material genético de todo individuo condenado por um crime doloso contra pessoa de natureza grave cometido mediante violência, e posterior armazenamento dos perfis genéticos em banco de dados criminal. Isto implica no uso do sistema CODIS do FBI para a identificação genética de condenados por crimes de natureza grave - crime contra a pessoa (homicídio, lesão corporal de natureza grave, aborto etc.) e crimes Hediondos (estupro, homicídio quando praticado por grupo de extermínio, latrocínio, extorsão qualificada pela morte etc.).

No entanto, nesse momento, alguns aspectos em relação à Lei 12.654/2012, tal como ela foi elaborada, são questionados. São eles: a falta de garantia de qualidade dos laboratórios oficiais responsáveis pelas análises do DNA; a criação de um sistema de controle da atividade e funcionamento do banco, como a criação de um conselho fiscalizador que possa assegurar a transparência do processo na tentativa de promover um aumento da confiabilidade desses bancos perante a sociedade; e ausência de um dispositivo específico que trate sobre o armazenamento das amostras biológicas e a possibilidade de destruição das mesmas.

Haja vista, o artigo $5^{\circ}$, que trata sobre o armazenamento dos perfis genéticos em banco de dados, não especificar qual o procedimento a ser adotado no caso das regiões do DNA utilizadas na identificação humana passarem a revelar características somáticas e comportamentais dos indivíduos. Essa possibilidade é ponderada ao se considerar os constantes avanços científicos no campo da genética forense. Como se pode observar a seguir.

\footnotetext{
Art. 5o-A. Os dados relacionados à coleta do perfil genético deverão ser armazenados em banco de dados de perfis genéticos, gerenciado por unidade oficial de perícia criminal.

§ 1o As informações genéticas contidas nos bancos de dados de perfis genéticos não poderão revelar traços somáticos ou comportamentais das pessoas, exceto determinação genética de gênero, consoante as normas constitucionais e internacionais sobre direitos humanos, genoma humano e dados genéticos.

§ 20 Os dados constantes dos bancos de dados de perfis genéticos terão caráter sigiloso, respondendo civil, penal e administrativamente aquele que permitir ou promover sua utilização para fins diversos dos previstos nesta Lei ou em decisão judicial.
}

O parágrafo $2^{\circ}$, desse artigo por sua vez, não aborda a questão do armazenamento das amostras biológicas e a possibilidade de descarte das mesmas, tendo em vista seu grau de importância. 
Cabe aqui uma análise comparativa com a criação do banco de dados de perfis genéticos criminais, ocorrida em Portugal no ano de 2008. O banco português foi apresentado como uma ferramenta revolucionária no combate à criminalidade, tendo como objetivo auxiliar nas investigações criminais e na identificação de suspeitos. No entanto, embora tenha ocorrido uma profunda discussão quanto às questões legais e éticas suscitadas pelo uso de um banco desta natureza, e quanto à necessidade de sua implantação, até o início do ano 2012, o banco português não conseguiu apresentar a eficiência prometida.

Um dos motivos alegados para essa possível ineficiência é a grande restrição da lei, pois segundo a Procuradoria Geral da República Portuguesa, os juízes nem sempre determinam a coleta de material genético de condenados a pena igual ou superior a três anos de prisão, e que em várias situações não estão presentes os requisitos legais para a coleta de amostras biológicas e posterior inclusão do perfil genético no referido banco.

Entretanto, a presidente da Comissão Nacional de Proteção de Dados de Portugal, Filipa Calvão, em sua apresentação na Conferência "Bases de Dados Genéticos - a ética, o direito e a investigação criminal” (Universidade do Minho/Portugal, em março de 2013), elogiou todo o cuidado que os legisladores tiveram na elaboração da lei portuguesa que criou a Base de Perfis de DNA deste país. Destacou, ainda, que as medidas de segurança adotadas são consideradas um exemplo para o resto do mundo.

Alerta-se aqui, para a visão de Lorente Acosta (2002, p. 1-25) no que diz respeito à necessidade de um estudo prévio sobre a criminalidade no país, ressaltando os índices de violência atualizados dos últimos 10 ou 20 anos e as possibilidades para seu controle, para somente depois disso lançar mão da ferramenta banco de perfis genéticos criminais.

Com a publicação do Decreto 7.950, em março de 2013, regulamentou-se a Lei 12.654/2012 e institui-se o banco nacional de perfis genéticos e a rede integrada de bancos de perfis genéticos. Estabelecendo, ainda, a unidade de perícia oficial do Ministério da Justiça como o âmbito de gestão do banco.

A rede integrada de bancos de perfis genéticos tem como escopo consentir o compartilhamento e a comparação de perfis genéticos incluídos nos bancos da União, dos Estados e do Distrito Federal. A adesão dos Estados e do Distrito Federal à rede acontecerá mediante convênio de cooperação técnica entre o Ministério da Justiça e as Unidades da Federação. 
O decreto, em seu artigo $2^{\circ}$, firma a criação de um comitê Gestor, que promoverá a coordenação das ações dos órgãos gerenciadores de banco de dados de perfis genéticos e a integração dos dados nos seus respectivos âmbitos: União, Estados e Distrito Federal.

É válido lembrar a possibilidade de participação de um membro da Comissão Nacional de Ética em Pesquisa (CONEP) nas reuniões desse comitê, bem como um membro da Ordem dos Advogados do Brasil (OAB).

As funções desse comitê encontram-se dispostas no artigo $5^{\circ}$, dentre elas: a obrigação de definir medidas e padrões que vão assegurar o respeito aos direitos e garantias individuais, nos procedimentos de coleta, de análise e de inclusão, e no armazenamento e manutenção dos perfis genéticos nos bancos de dados; o comprometimento de definir medidas que assegurem a confiabilidade e o sigilo dos dados; e ainda o empenho em definir requisitos técnicos para que auditorias sejam realizadas no banco e na rede integrada de perfis genéticos.

Com isso o governo brasileiro sinaliza uma preocupação em resguardar direitos e liberdades dos indivíduos que terão seus perfis genéticos armazenados no banco. Para tanto, é necessário que os procedimentos envolvidos no exame de DNA para obtenção do perfil genético, sejam rigorosos quanto à qualidade e que o acesso às informações produzidas seja bastante restrito.

$\mathrm{O}$ artigo $7^{\circ}$ trata de um aspecto considerado de grande relevância nas legislações de países que possuem bancos com essa finalidade, o prazo para a eliminação do perfil genético do banco. Dessa forma, fica definido nesse artigo que o perfil genético do indivíduo identificado criminalmente será eliminado logo depois de decorrido o prazo de prescrição do crime. Haja vista, que com a prescrição do crime encerra-se, também, a obrigação e o pré-requisito básico que determinam o armazenamento do perfil genético na base de dados.

A legislação britânica, nesse sentido, determina a detenção dos perfis genéticos e das respectivas amostras biológicas que os originaram, por tempo ilimitado. Este aspecto indica o atraso legal e ético em que se encontra o banco inglês.

Vale destacar que o banco nacional de perfis genéticos também será utilizado para a identificação de pessoas desaparecidas, e que os perfis genéticos de familiares de desaparecidos serão incluídos no banco de dados, com finalidade única de identificação destes. Este será um típico exemplo de voluntariado para a inclusão de perfil genético no banco.

No entanto, já existe no cenário nacional um banco de dados de DNA com finalidade semelhante, o banco de perfis genéticos de crianças e adolescentes desaparecidos, criado em 
2009, utilizado para identificar crianças e adolescentes desaparecidos por meio de estudos de vínculo genético entre estes e a sua família.

\section{CONSIDERAÇÕES FINAIS}

O grande desenvolvimento tecnológico adquirido pelas ciências biológicas, em especial, pela biológica molecular, tem proporcionado inúmeras possibilidades de suas aplicações, a exemplo das tecnologias de análises genéticas no campo forense. A identificação humana a partir de técnicas de análise de DNA tem propiciado a vinculação de indivíduos a determinado crime e, consequentemente, a identificação da autoria do mesmo.

A criação e utilização do banco nacional de perfis genéticos criminal no Brasil, com o objetivo de identificar a autoria de crimes que não apresentam suspeitos, é um tema polêmico e que merece ser amplamente discutido na sociedade, a partir do envolvimento da Bioética área que abarca vários campos do conhecimento -, este artigo tratou dos aspectos bioéticos envolvidos na implantação e no uso dessa nova ferramenta.

É importante destacar as limitações inerentes ao tema abordado, como a escassez de estudos específicos, por se tratar de um tema relativamente novo. Devido à existência de um viés legal, houve uma atenção permanente no sentido de não incorrer no risco de se realizar uma abordagem menos bioética e mais legalista.

Considerando as complexas especificidades do tema, não se tem aqui a pretensão de esgotá-lo e muito menos de se chegar a conclusões definitivas, mas subsidiar novos estudos, como também contribuir para uma elaboração possível de políticas públicas sobre essa temática.

O objetivo geral deste artigo foi proporcionar uma discussão sobre os aspectos bioéticos envolvidos na criação do banco de perfis genéticos criminal no Brasil e sobre a importância real do estudo do diploma legal da lei 12.654/2012. .

Apesar das inquietações apresentadas pelos avanços tecnológicos, houve uma revitalização da reflexão ética no Direito, no sentido de repensar os valores que informam o Direito, como a autonomia, a liberdade e a dignidade humana. É percebida a necessidade de recuperar o sentido de dever moral, anterior à própria lei e de sua dimensão crítica. Justamente por essa razão, a ideia de autolimitação voluntária, continua sendo um tema de reflexão 
importante, no sentido moral, de assumir a autonomia, legada pela modernidade, de maneira responsável, seja individual ou coletivamente (BARRETO; SCHIOCCHET, 2005).

A bioética é um campo do saber que proporciona uma análise transdisciplinar com autoridade de problematizar e tentar aprofundar a discussão sobre os pontos nevrálgicos da catalogação dos perfis genéticos. Com efeito, o manejo e regulação da informação genética apoiam-se em documentos internacionais, transportados para normas jurídicas nacionais, diretrizes de conduta, princípios interventivos, políticas institucionais de proteção da privacidade e de acesso aos dados e nos mecanismos de governança, que se encarregam de fiscalizar e aplicar esse aparato ético e normativo.

Ao sustentarmos a urgência da politização das tecnologias e de sua regulação jurídica, acreditamos que outros caminhos podem ser trilhados na relação entre os humanos e os objetos técnicos. A manifestação bioética enlaça e incorpora os conceitos biopolíticos. Dessa forma, a bioética se preocupa com as práticas biopolíticas e seus usos inadequados. Pode ser entendida, portanto, como uma ferramenta analítica e normativa da moralidade da biopolítica quanto como uma aplicação prática sob a forma de resistência democrática com relação aos efeitos moralmente questionáveis.

Conclui-se, portanto, que a catalogação dos dados genéticos em bases de dados informatizadas para elucidação de crimes não fere o respeito à autonomia, pois há uma previsão legal nessa ordem. Também não interfere na privacidade, confidencialidade do indivíduo, pois dão condições técnicas e operacionais claras da não interferência humana à informação individual. E, de fato, preserva a justiça do ato, ao estabelecer limites na conduta humana, pois tem o propósito de apenar o indivíduo condenado a ter sua inclusão no banco de dados genéticos. 


\section{REFERÊNCIAS BIBLIOGRÁFICAS}

ACOSTA, JAL. Identificación Genética Criminal: importância médico legal de las bases de datos de DNA. In.: Romeu Casabona, CM. Bases de datos de perfiles de ADN y Criminalidad. Bilbão-Granada, 2002; p.1-25.

AGUIAR, SM et al. Rede Integrada de Bancos de Perfis Genéticos e a implantação do CODIS no Brasil. Anais do III Congresso Brasileiro de Genética Forense. SBG. Porto Alegre, 2011.

ALMEIDA NETO, JB. Banco de Dados Genéticos para Fins Criminais: aspectos jurídicos. PUCRS, Porto Alegre 2008.

ASSEMBLEIA DA REPÚBLICA (Portugal). Lei No 5/2008 - Aprova a criação de uma base de dados de perfis de ADN para fins de identificação civil e criminal. Diário da República, $1^{\mathrm{a}}$ série $-\mathrm{n}^{\mathrm{o}}$ 30-12 de fevereiro de 2008 .

BARALDI, AM. Utilização da Técnica de Identificação Genética: panorama da realidade dos serviços oficiais de identificação brasileiros. Banco de tese da USP, São Paulo, 2008.

BARRETTO, Vicente de Paulo; SCHIOCCHET, Taysa. Bioética: dimensões biopolíticas e perspectivas normativas. In: STRECK, L.L.; ROCHA, L.S. Anuário do Programa de PósGraduação em Direito - UNISINOS. Porto Alegre: Livraria do Advogado, 2005.

BECK, Ulrich. A Reinvenção da Política: rumo a uma teoria da modernização reflexiva. In.: Giddens A; Beck U; Lash S. Modernidade Reflexiva: política, tradição e estética na ordem social moderna. Editora Unesp. São Paulo, 1997. p. 11-74.

BEECHER, H. Ethics and Clinical Research. In: The New England Journal of Medicine. 1354-1360.1966.

BONACCORSO, Norma S. Aspectos Técnicos, Éticos e Jurídicos Relacionados com a criação de Bancos de Dados Criminais de DNA no Brasil (Tese). São Paulo (SP). Faculdade de Direito da Universidade de São Paulo - USP, 2010.

CASABONA, Carlos Maria Romeo. Prólogo. In.: Casabona CMR. Bases de datos de perfiles de ADN y criminalidade. Bilbão-Granada: Comares, 2002.

COLE, S. The myth of fingerprints. Gene watch opinion piece. 2002. [Acesso em 2015 jan 08]. Disponível em: http://www.gene-watch.org/genewatch/articles/19-6Cole.html.

Combined DNA Index System (CODIS). Brochure: offender/forensic profiles \& total offender hits. Washington, EUA, 2013. [Acesso em 2015 jan 20]. Disponível em: <http://www.fbi.gov/hq/lab/html/codisbrochure_text.html.

COSTA, Susana. A justiça em laboratório. Ed. Almedina, Coimbra-Portugal, 2003. 
CRUZ, MR; CORNELLI, G. (Bio)Ética e (Bio)Tecnologia. Revista Brasileira de Bioética (RBB).Vol. 6 n. 1-4, pg 115-138. 2010.

ESPINDULA, Alberi. Pericia Criminal. Uma visão completa para peritos e usuários da perícia. $3^{\mathrm{a}}$ ed. Millennium, 2009.

GARCÍA, O; Alonso, A. Las Bases de Datos de Perfiles de ADN como instrumento en la investigatión Policial. In: Casabona CMR. Bases de datos de perfiles de ADN y Criminalidad. Bilbão-Granada, 2002. p.27-43.

GARRAFA, Volnei. Clonagem Humana: prós e contras. Revista Scientific American, São Paulo-SP, 2003; v. 2, p. 56-57.

Da bioética de princípios a uma bioética interventiva. Rev. Bioética. Vol 13, $\mathrm{n}^{\circ}$ 1.

2005 .

Multi-inter-transdisciplinaridade, complexidade e totalidade concreta em bioética. In: Garrafa V, Kottow M, Saada A. (orgs). Bases conceituais da bioética -enfoque latino-americano. Ed. Gaia. São Paulo (SP). 2006.

GARRIDO, Rodrigo Grazinoli. Evolução dos Processos de Identificação Humana: das características antropométricas ao DNA. Revista Genética na escola. 2009; v2, p.38-40.

GATTÁS, GJF; GARCiA, CF. Caminho de Volta: tecnologia na busca de crianças e adolescentes desaparecidos no Estado de São Paulo. SP, YM Gráfica ltda, 2007.

JOBIM, LF et al. Identificação Humana: identificação pelo DNA. Millennium Editora, v. II. Campinas - SP, 2006.

JUNGES, José Roque. O nascimento da bioética e a constituição do biopoder. Revista Acta Bioethica. Número 17 (2), pg 171-178, 2011.

KOTTOW, MH. Salud Pública, Genética y Ética. Rev. Saúde Pública, São Paulo, 2002; v 36, n. 5.

LIMA, HB. DNA x Criminalidade. Revista Perícia Federal - APCF. Brasília, 2008; ano IX - n. 26: p.8-11.

MACHADO, $\mathrm{H}$. Construtores da bio(in)segurança na base de dados de perfis de ADN. Rev. Etnográfica, 2011; 15(1): p.153-166.

MACHADO, H, Silva S. Confiança, Voluntariedade e Supressão dos Riscos: expectativas, incertezas e governação das aplicações forenses de informação genética. In Frois C. A sociedade vigilante: ensaios sobre privacidade, identificação e vigilância. Lisboa: Imprensa de Ciências Sociais, 2008; p.151-174. 
MARANO LA, Simões AL, Oliveira SF, Mendes Junior CT. Polimorfismos Genéticos e Identificação Humana: o DNA como prova forense. Revista Genética na escola. 2010; v 05.01, p53-56.

MORA Sánchez JM. Propuestas para la Creación y Regulación Legal em Espanã de una Bases de Datos de ADN con Fines de Identificación Criminal. In.: Casabona CMR. Bases de datos de perfiles de ADN y Criminalidad. Bilbão-Granada, 2002. p.45-73.

NATIONAL DNA DATABASE (NDNAD). Annual Report 2007-09. London, UK: The Forensic Science Service. 2010.

NATIONAL DNA DATA BANK OF CANADA (NDDB). Annual Report 2011-2012. Canada, 2013. [Acesso em 2015 jan 20]. Disponível em: <http://www.publicsafety.gc.ca/prg/cor/tls/dna-eng.aspx.

PRESIDÊNCIA DA REPÚBLICA (Brasil). Casa Civil. Decreto n 7.950/12 de março de 2013. PRESIDÊNCIA DA REPÚBLICA (Brasil). Casa Civil. Lei no 12.654/2012.

SCHRAMM, FR; Palácios, M; Rego, S. O modelo bioético principialista para a análise da moralidade da pesquisa científica envolvendo seres humanos ainda é satisfatório? Revista Ciência e Saúde Coletiva. 13(2): 361-370, 2008.

SCHIOCCHET, Taysa. Bancos de Perfis Genéticos Para Fins de Persecução Criminal. Relatório nº 43, Ministério da Justiça. São Leopoldo, Brasil, 2012.

VÁZQUEZ, Margarita Guillén. Bases de Datos de ADN con Fines de Investigación Penal: especial referencia al derecho comparado. In Estudios Jurídicos. Espanha, 2004; p.19902022. 